\title{
Activation of Chloride Secretion by Isoflavone Genistein in Endometrial Epithelial Cells
}

\author{
Chatsri Deachapunya ${ }^{a}$ Sutthasinee Poonyachotib \\ aDepartment of Physiology, Faculty of Medicine, Srinakharinwirot University, Bangkok, bDepartment \\ of Physiology, Faculty of Veterinary Science, Chulalongkorn University, Bangkok, Thailand
}

\section{Key Words}

Daidzein • Phytoestrogen • Chloride transport • UTP • Endometrial epithelium

\begin{abstract}
Background /Aim: Genistein, the most active isoflavone found primarily in soybeans, alters ion transport functions in intestinal and airway epithelia. The present study aims to investigate the acute effects and mechanisms of action of genistein in immortalized porcine endometrial epithelial cells. Methods: Ussing chamber technique was used for transepithelial electrical measurements. Results: Genistein increased short-circuit currents $\left(\mathrm{I}_{\mathrm{sc}}\right)$ which were inhibited by glibenclamide, NPPB, CFTRinh-172, DIDS or bumetanide, but not amiloride. In experiments with amphotericin B-permeabilized monolayers, genistein activated the apical $\mathrm{Cl}^{-}$current and barium-sensitive basolateral $\mathrm{K}^{+}$current while inhibiting the apical $\mathrm{K}^{+}$current. Genistein failed to increase the $\mathrm{I}_{\mathrm{sc}}$ in the presence of forskolin or IBMX, but did increase the $\mathrm{I}_{\mathrm{sc}}$ in UTP. Pretreatment with genistein also abolished the increase in the $\mathrm{I}_{\mathrm{sc}}$ when induced by forskolin, IBMX or UTP. However, $\mathrm{Ca}^{2+}$-chelating BAPTA-AM did not affect the genistein-induced increase in the $I_{\text {sc }}$. The genistein-stimulated $I_{\text {sc }}$ was reduced by tyrosine kinase inhibitors, tyrphostin A23 or AG490. However, vanadate, a tyrosine phosphatase inhibitor, failed to inhibit the genistein response. Estrogen receptor antagonist ICI182,780 did not alter the genistein's action. Conclusion: The soy isoflavone, genistein, stimulates $\mathrm{Cl}^{-}$secretion in endometrial epithelial cells possibly via a direct activation of CFTR which appears to be modulated through a tyrosine kinase-dependent pathway. The present findings may be of benefit for the therapeutic application of genistein in the treatment of electrolyte transport disorders in the epithelia.
\end{abstract}




\section{Introduction}

Genistein is a naturally occurring isoflavone found primarily in leguminous plants with soybeans and it's by products with especially high concentrations [1]. As its chemical structure relates to estradiol, an endogenous estrogen, genistein can bind to estrogen receptors [2] and exert weak estrogenic and/or antiestrogenic effects on numerous cells and tissues both in vitro and in vivo [3]. Consuming soy-based foods has been suggested to have potential health benefits; for example, reduced risks of cardiovascular diseases, lower blood pressure, reduced incidences of osteoporosis, and reduced risks for breast and endometrial cancers $[4,5]$. However, its underlying mechanisms are unclear and some adverse effects of genistein on the female reproductive tract have been reported [6, 7].

The regulation of electrolyte composition and fluid volume within the uterine cavity provides an optimal intrauterine environment that is required for the reproductive events of gamete transport and embryo development [8]. Sex-steroid hormones, estrogen and progesterone, are associated with local factors of cytokines and growth factors that orchestrate the control of the activities of the epithelia's surface and glandular transport systems $[8,9]$. Alteration in uterine ionic composition observed in hydrosalpinx or cystic fibrosis have been associated with many reproductive failures, pathologic reproductive conditions, infertility and recurrent pregnancy losses [10].

The isoflavone genistein has been shown to alter ion transport in both native epithelia and cultured epithelial cells. It stimulates $\mathrm{Cl}^{-}$secretion in rat colons, mouse intestines, human colonic cell lines and airway epithelia [11-14]. A number of transporter proteins involved in $\mathrm{Cl}^{-}$secretion including the cystic fibrosis transmembrane conductance regulator (CFTR), $\mathrm{K}^{+}$channels, and $\mathrm{Na}^{+}-\mathrm{K}^{+}-2 \mathrm{Cl}^{-}$cotransporters have been modulated by genistein $[11,12,15]$. Recently, genistein has been proposed as a promising therapeutic agent for cystic fibrosis through its modulation of transport proteins involved in $\mathrm{Cl}^{-}$secretion [16].

Several molecular mechanisms of genistein's action on CFTR activity have been proposed. These include the modulation of tyrosine kinases [17], protein phosphatases [18], protein kinases [19] and the direct activation of CFTR $[17,20]$. Genistein has been shown to activate the CFTR via a tyrosine-dependent phosphorylation pathway as its effect is abolished by the tyrosine phosphatase inhibitor vanadate $[11,14,21]$. However, genistein also stimulates the CFTR in the presence of vanadate [22]. In addition, tyrphostin A23 and tryphostin A51, tyrosine kinase inhibitors that are structurally different from genistein, do not activate $\mathrm{Cl}^{-}$ secretion in T84 cells [23]. In addition, a tyrphostin A23 pretreatment is found to reduce the genistein-stimulated $\mathrm{Cl}^{-}$secretions in rat jejunums [24]. Other studies have demonstrated a direct interaction of genistein with CFTR at nuclear binding domain 2 via tyrosine kinaseand protein phosphatase independent mechanisms [17, 20]. In CFTR overexpressing cells, genistein has been shown to produce a biphasic effect on CFTR gating (i.e., stimulatory effects at low concentrations and inhibitory effects at high genistein concentrations [22]). Thus, the role of genistein on the phosphorylation and dephosphorylation-dependent regulation of CFTR is not well defined and appears to be tissue or cell-specific and concentration dependent. Other mechanisms of genistein's action involve an increased CFTR localization to the plasma membrane $[25,26]$ and a stimulation of $\mathrm{Cl}^{-}$secretion via inhibition of the phosphodiesterase-dependent pathway [24].

Electrophysiological studies of both intact endometrial epithelium and cultured endometrial epithelial cells have provided direct evidence for the regulation of $\mathrm{Na}^{+}$absorption, $\mathrm{K}^{+}$secretion [27-30] and $\mathrm{Cl}^{-}$secretion [31-33]. Although genistein exerts transport-related effects on a variety of epithelial cells, little is known regarding the direct effects of genistein on the ion transport functions of the endometrial epithelium. Therefore the aim of this study is to investigate the acute effects and the mechanism of action of genistein on ion transport function in an immortalized porcine endometrial epithelial cell line. These cells express estrogen receptors both alpha and beta subtype (unpublished data) and exhibit functionally characterized CFTR and other transport proteins for $\mathrm{Cl}^{-}$and $\mathrm{K}^{+}$secretion [34, 35]. This 
provides a suitable model for studying the transport-related properties of estrogen-like substances.

\section{Materials and Methods}

\section{Materials}

Genistein, daidzein, forskolin, 3-isobutyl-1-methylxanthine (IBMX), uridine-5'-triphosphate (UTP), amiloride, 5-nitro-2-(3-phenylpropylamino) benzoic acid (NPPB), glibenclamide, 4,4'-diisothiocyanatostilbene-2,2-disulfonic acid (DIDS), bumetanide, 1,2-bis(o-aminophenoxy)ethane- $\mathrm{N}, \mathrm{N}, \mathrm{N}^{\prime}, \mathrm{N}^{\prime}$-tetraacetic acid (BAPTA-AM), tyrphostin A23, AG490, sodium orthovanadate (vanadate), $7 \alpha$-[9-(4,4,5,5,5-pentafluoro-pentylsulphinyl)nonyl]oestra-1,3,5(10)-triene-3,17 $\beta$-diol (ICI182,780), 17 $\beta$-estradiol, $\mathrm{BaCl}_{2}$, insulin, non-essential amino acid, L-glutamine and high purity grade salts were purchased from Sigma Chemical Co (St. Louis, MO). Dulbecco modified Eagle's medium (DMEM), fetal bovine serum (FBS), 0.05\% trypsin- 0.53 mM ethylenediaminetetraacetic acid (EDTA), kanamycin, and penicillin-streptomycin were purchased from Gibco (Grand Island, NY).

\section{Cell culture}

Immortalized porcine endometrial gland epithelial cells (PEG cells) were kindly provided by Professor Scott O'Grady, University of Minnesota. The PEG cells were primary endometrial epithelial cells that were stably transfected with the catalytic subunit of human telomerase [35]. The PEG cells (passage number 62-80) were cultured in DMEM supplemented with $3.7 \mathrm{~g} / \mathrm{L} \mathrm{NaHCO}_{3}, 10 \%$ heat-inactivated FBS, $850 \mathrm{nM}$ (5 $\mu \mathrm{g} / \mathrm{ml}$ ), insulin, $1 \%$ non-essential amino acid, $100 \mathrm{U} / \mathrm{ml}$ penicillin, $100 \mu \mathrm{g} / \mathrm{ml}$ streptomycin and $100 \mu \mathrm{g} / \mathrm{ml}$ kanamycin, and incubated at $37^{\circ} \mathrm{C}$ in a humidified atmosphere of $5 \% \mathrm{CO}_{2}$ in air. The cells were then seeded onto $24 \mathrm{~mm}\left(4.5 \mathrm{~cm}^{2}\right)$ transparent permeable membrane filters (Costar, Cambridge, MA, USA) for 7-10 days prior to the experiment.

\section{Measurement of electrical parameters}

Transpithelial resistance of cell monolayers was measured with an EVOM epithelial voltohmmeter coupled to Ag/AgCl 'chopstick' electrodes (World Precision Instruments, Sarasota, FL, USA). Monolayers with high resistance $\left(\approx 3000 \Omega \mathrm{cm}^{2}\right.$ ) were then mounted in Ussing Chambers, bathed on both sides with standard porcine Ringer solution (in mM: $111.5 \mathrm{KCl}, 25 \mathrm{NaHCO}_{3}, 1.8 \mathrm{Na}_{2} \mathrm{HPO}_{4}, 0.2 \mathrm{NaH}_{2} \mathrm{PO}_{4}, 1.25 \mathrm{CaCl}_{2}, 1.0$ $\mathrm{MgSO}_{4}$ and 12 glucose) which was maintained at $37^{\circ} \mathrm{C}$ and bubbled with $95 \% \mathrm{O}_{2}-5 \% \mathrm{CO}_{2}$. Transepithelial potential difference (PD) and short circuit current $\left(\mathrm{I}_{\mathrm{sc}}\right.$ ) were measured with a voltage-clamp circuitry (EVC4000, WPI) with $\mathrm{Ag} / \mathrm{AgCl}$ electrodes connected to the bathing solution via agar bridges. Transepithelial conductance $(G)$ was calculated using the Ohm's law (G= $\left.I_{s c} / P D\right)$. The monolayer was continuously shortcircuited, except for a brief interval of open-circuited readings for PD measurements before and after the addition of any chemicals. Data from the voltage clamp was connected to a MacLab 4S A/D converter and then the data was stored in a Macintosh $400 \mathrm{MHz}$ PowerPC. After mounting on Ussing chamber, the monolayer was equilibrated for a minimum of 30 minutes to achieve a stable $\mathrm{I}_{\mathrm{sc}}$ before the addition of test substances. A positive $\mathrm{I}_{\mathrm{sc}}$ corresponded with the movement of the positive charge from the apical to the basolateral compartments or resulted from the movement of negative charges from the basolateral to apical compartments or were the result of a combination of both processes.

In the experiments with measurement of membrane permeability, an apical membrane current was determined by permeabilization of the basolateral membrane of the monolayers mounted in the Ussing chambers with amphotericin B $(10 \mu \mathrm{M})$. The permeabilized basolateral membrane was bathed with a $\mathrm{KMeSO}_{4}$ Ringer solution (in mM: $120 \mathrm{KMeSO}_{4}, 30$ mannitol, $5 \mathrm{NaCl}, 3$ calcium gluconate, $1 \mathrm{MgSO}_{4}, 20 \mathrm{KHCO}_{3}$, $0.3 \mathrm{KH}_{2} \mathrm{PO}_{4}, 1.3 \mathrm{~K}_{2} \mathrm{HPO}_{4}$ ) while the apical membrane was bathed with a high concentrate $\mathrm{KCl}$ Ringer solution (in mM: $120 \mathrm{KCl}, 30$ mannitol, $5 \mathrm{NaCl}, 3$ calcium gluconate, $1 \mathrm{MgSO}_{4}, 20 \mathrm{KHCO}_{3}, 0.3 \mathrm{KH}_{2} \mathrm{PO}_{4}, 1.3 \mathrm{~K}_{2} \mathrm{HPO}_{4}$ ) for apical $\mathrm{Cl}^{-}$current $\left(\mathrm{I}_{\mathrm{Cl}}\right)$ measurements or with $\mathrm{NaMeSO}_{4}$ Ringers solution (in mM: $120 \mathrm{NaMeSO}_{4}, 30$ mannitol, $5 \mathrm{NaCl}, 3$ calcium gluconate, $\left.1 \mathrm{MgSO}_{4}, 20 \mathrm{KHCO}_{3}, 0.3 \mathrm{KH}_{2} \mathrm{PO}_{4}, 1.3 \mathrm{~K}_{2} \mathrm{HPO}_{4}\right)$ for apical K+ current ( $\left.\mathrm{I}_{\mathrm{Ka}}\right)$ measurements. The basolateral membrane $\mathrm{K}^{+}$current $\left(\mathrm{I}_{\mathrm{Kb}}\right)$ measurement was performed by amphotericin B-permeabilized apical membrane bathed with a $\mathrm{KMeSO}_{4}$ Ringer solution, and the basolateral membrane was bathed with a $\mathrm{NaMeSO}_{4}$ Ringer solution. All solutions were adjusted to a $\mathrm{pH}$ of 7.4 at a temperature of $37^{\circ} \mathrm{C}$. 
Fig. 1. Effects of genistein and daidzein on basal $\mathrm{I}_{\mathrm{sc}}$ of the immortalized porcine endometrial epithelial cells. Representative $I_{\text {sc }}$ tracings in response to $(\mathrm{A})$ genistein $(100 \mu \mathrm{M}$, apical and basolateral), (B) daidzein (50 and 100 $\mu \mathrm{M}$, apical and basolateral) and subsequently to genistein. (C) Changes in $\mathrm{I}_{\mathrm{sc}}$ induced by genistein at concentrations of 0.1 $100 \mu \mathrm{M}$. (D) Analysis of concentration-dependent responses for the genistein-induced increase in $\mathrm{I}_{\mathrm{sc}}$ show the $\mathrm{EC}_{50}$ value of $9.39 \mu \mathrm{M}(\mathrm{n}=5)$.
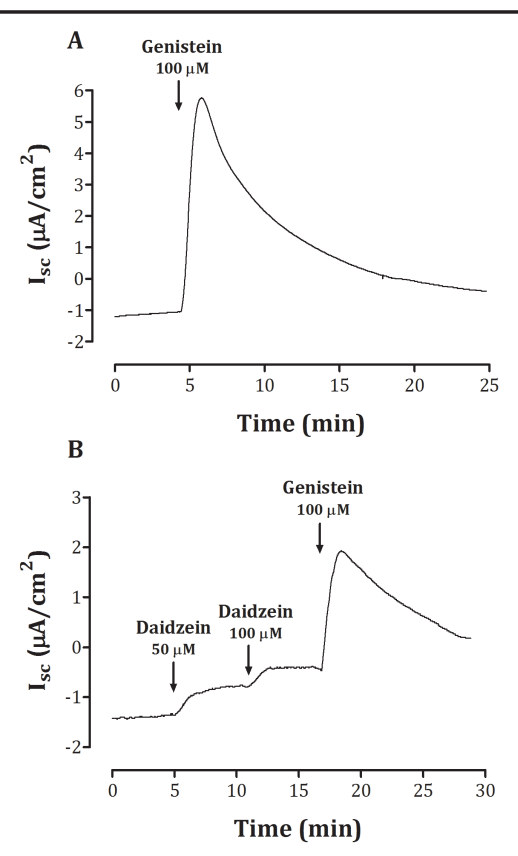

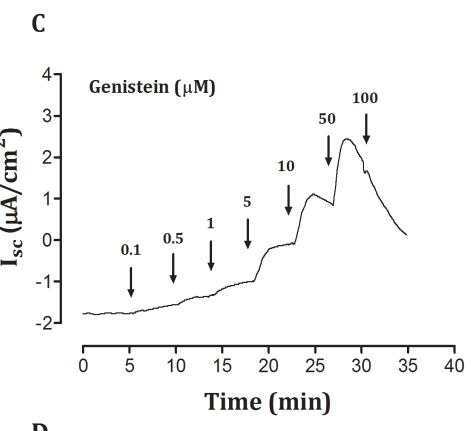

D

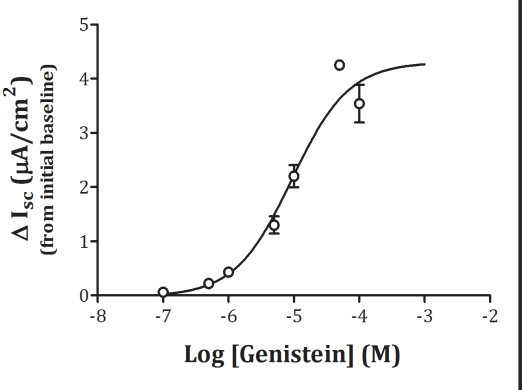

Fig. 2. Effects of $\mathrm{Na}^{+}$and $\mathrm{Cl}^{-}$channel blockers and $\mathrm{Na}^{+}-\mathrm{K}^{+}-2 \mathrm{Cl}^{-}$cotransport blockers on the genisteinstimulated $\mathrm{I}_{\mathrm{sc}}$ of the immortalized endometrial epithelial cells. Bar graph shows the average changes in $\mathrm{I}_{\mathrm{sc}}$ as induced by genistein (Gen; $50 \mu \mathrm{M}$, apical and basolateral) alone and in the presence of the $\mathrm{Na}^{+}$channel blocker amiloride (Amil;10 $\mu \mathrm{M}$, apical), $\mathrm{Cl}^{-}$channel blockers NPPB (100 $\mu \mathrm{M}$, apical), glibenclamide (Gli; $200 \mu \mathrm{M}$, apical), CFTRinh-172 (20 $\mu \mathrm{M}$, apical) or DIDS $\left(200 \mu \mathrm{M}\right.$, apical), or $\mathrm{Na}^{+}$$\mathrm{K}^{+}-2 \mathrm{Cl}^{-}$cotransporter blocker bumetanide (Bum; $200 \mu \mathrm{M}$, basolateral). Each value represents mean \pm SEM (n=3-6). $* \mathrm{P}<0.01$ when compared to the control group with genistein alone by Dunnett's test.

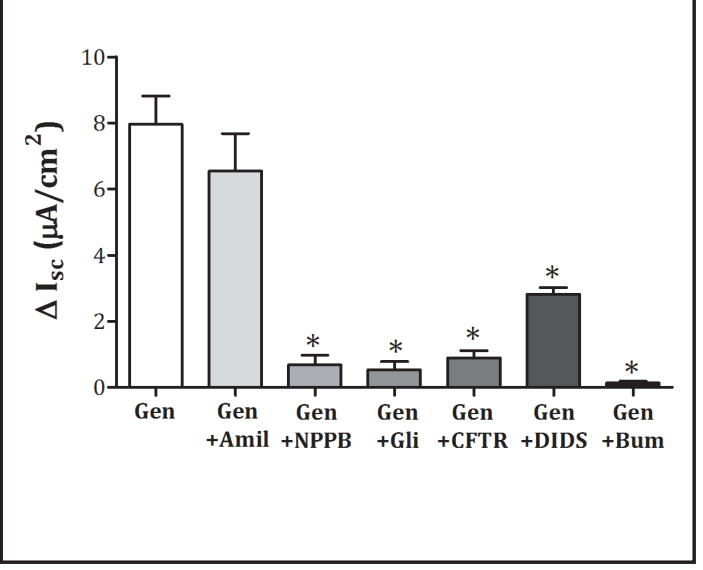

\section{Data analyses}

Data was presented as a mean \pm standard error of mean (S.E.M.), and $\mathrm{n}$ was the number of monolayers used in each experiment. The statistical differences between the control and experimental means were analyzed using a Student's t-test or Analysis of Variance (ANOVA) when appropriate. The difference between the treatment and the control mean, following a significant ANOVA, was identified by the Dunnett's test (Prism ${ }^{\mathrm{TM}}$ 5.00, GraphPad Software, Inc., San Diego, CA). A value of $\mathrm{P}<0.05$ was considered statistically significant.

\section{Results}

Genistein-induced increase in $I_{s c}$

Under basal conditions, PEG cell monolayers showed an average $I_{s c}$, potential difference (lumen negative) and transepithelial conductance values of $-0.62 \pm 0.24 \mu \mathrm{A} / \mathrm{cm}^{2}, 2.83$ $\pm 0.89 \mathrm{mV}$ and $0.22 \pm 0.04 \mathrm{mS} / \mathrm{cm}^{2}(\mathrm{n}=40)$, respectively. The addition of genistein $(100$ $\mu \mathrm{M}$ ) to the apical and basolateral solutions produced a transient increase in the $\mathrm{I}_{\mathrm{sc}}$ with a 
Fig. 3. Effect of genistein on the cAMP-activated $\mathrm{Cl}^{-}$ secretion of the immortalized endometrial epithelial cells. (A-B) Representative $\mathrm{I}_{\mathrm{sc}}$ tracings in response to genistein (Gen; $50 \mu \mathrm{M}$, apical and basolateral) in the presence of forskolin (For; $10 \mu \mathrm{M}$, apical and basolateral) or IBMX $(100 \mu \mathrm{M}$, apical and basolateral). (C) Average changes in the $\mathrm{I}_{\mathrm{sc}}$ in response to genistein alone and in the presence of forskolin or IBMX. (D-E) Representative $\mathrm{I}_{\mathrm{sc}}$ tracings responding to forskolin (10 $\mu \mathrm{M})$ or IBMX $(100 \mu \mathrm{M})$ in the presence of genistein $(50 \mu \mathrm{M})$. (F) Average changes in $\mathrm{I}_{\mathrm{sc}}$ in response to forskolin or IBMX alone and in the presence of genistein. Each value represents mean $\pm \mathrm{SEM}$ $(\mathrm{n}=4-6) . \quad * \mathrm{P}<0.01$ when compared to the corresponding control groups with compounds alone by Dunnett's test.

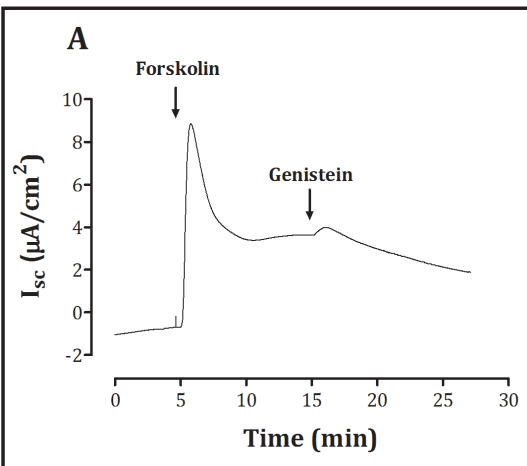

B

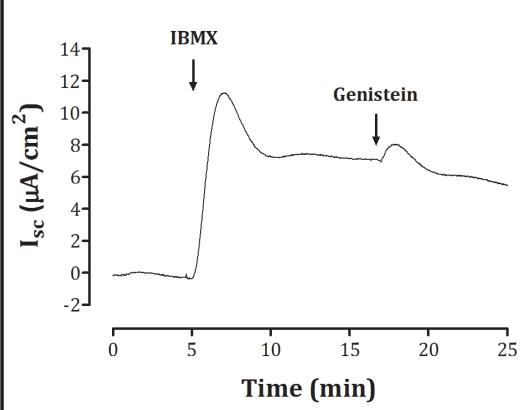

C

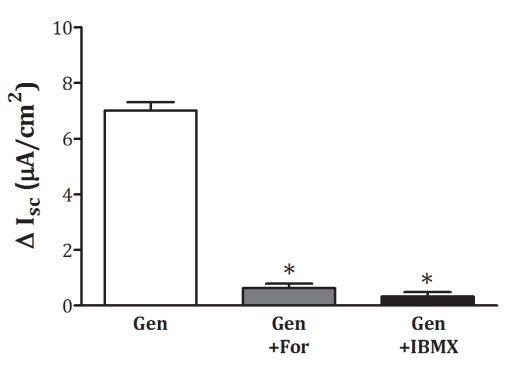

D

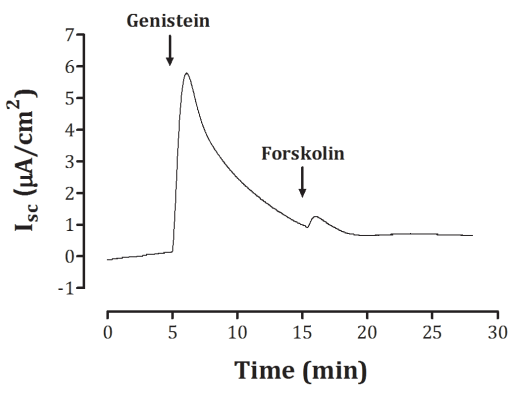

E

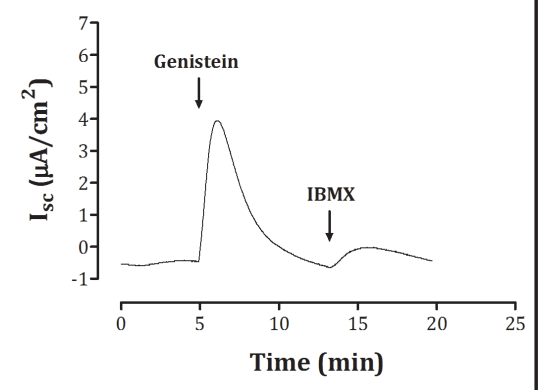

F

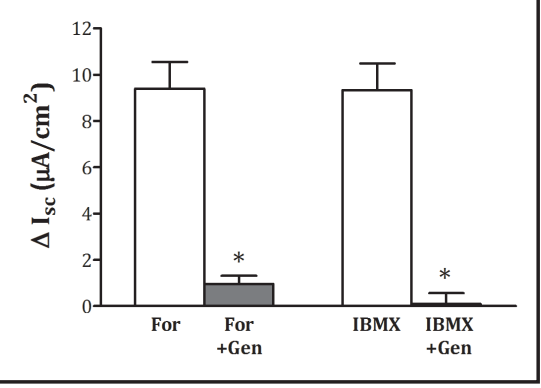

maximum effect of $7.41 \pm 0.87 \mu \mathrm{A} / \mathrm{cm}^{2}$ within $2-3 \mathrm{~min}$, followed by a gradual decrease in the $\mathrm{I}_{\mathrm{sc}}$ and was sustained at $2.17 \pm 0.79 \mu \mathrm{A} / \mathrm{cm}^{2}$ above the baseline ( $\mathrm{n}=9$, Fig. 1A). By contrast, the addition of daidzein (50 and $100 \mu \mathrm{M})$, an inactive analog of genistein, had shown a relatively small stimulatory effect on the basal $\mathrm{I}_{\mathrm{sc}}$. A subsequent addition of genistein (100 $\mu \mathrm{M}$ ) produced a further increase in the $I_{s c}$ (Fig. 1B). The accumulative $I_{s c}$ response induced by genistein was concentration dependent with an $\mathrm{EC}_{50}$ value of $9.39 \mu \mathrm{M}$ and a maximum response at a concentration of $50 \mu \mathrm{M}$ (Fig. 1C-D). As genistein at a higher concentration (100 $\mu \mathrm{M}$ ) did not increase the $\mathrm{I}_{\mathrm{sc}}$ further, the maximum response concentration of genistein (50 $\mu \mathrm{M}$ ) was used in the rest of the experiments. No changes in $\mathrm{I}_{\mathrm{sc}}$ were observed when the DMSO vehicle control was added at any point in time.

\section{Genistein-stimulated $\mathrm{Cl}$ secretion}

Previous studies have demonstrated the effects of genistein on modulating $\mathrm{Cl}^{-}$secretion in a variety of epithelia. Therefore, a series of experiments using various pharmacological channel blockers was conducted to determine the ionic basis involved in the increased $I_{s c}$ in response to genistein. As shown in Fig. 2, the increased $I_{s c}$ in response to genistein $(50$ $\mu \mathrm{M}$ ) was not affected by the presence of the apical $\mathrm{Na}^{+}$channel blocker $10 \mu \mathrm{M}$ amiloride. By contrast, the genistein response was mostly abolished in the presence of $100 \mu \mathrm{M}$ NPPB or $200 \mu \mathrm{M}$ glibenclamide, well-known cAMP-activated CFTR blockers, or $20 \mu \mathrm{M}$ CFTRinh-172, a specific CFTR blocker, in the apical solution. The presence of $200 \mu \mathrm{M}$ DIDS, a Ca ${ }^{2+}$-activated 
A

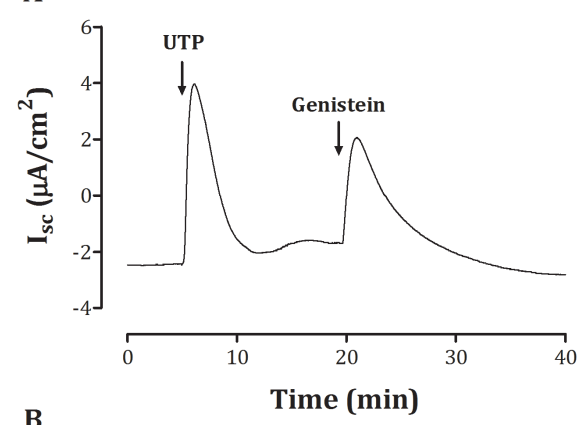

B

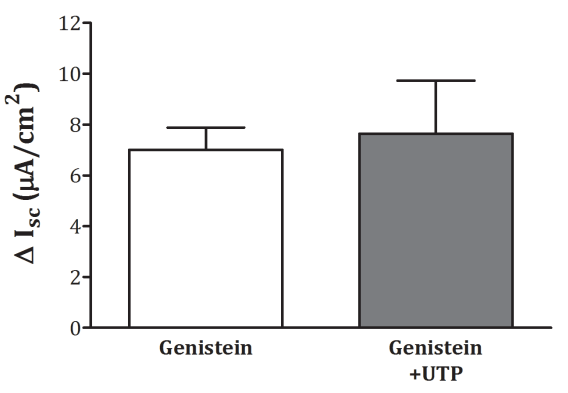

C

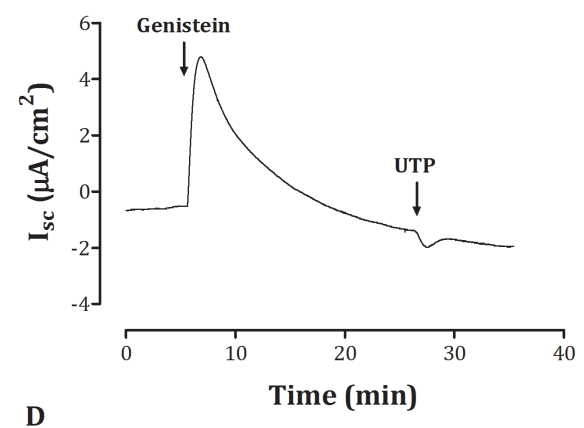

D

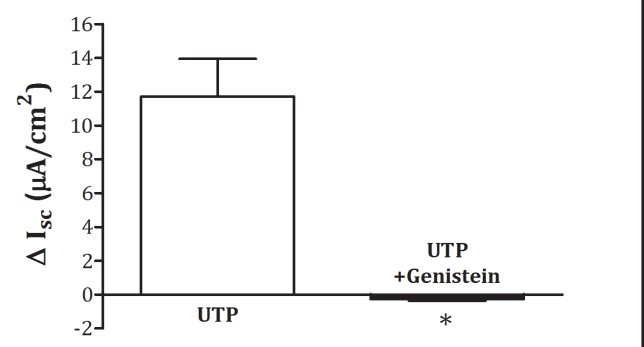

Fig. 4. Effect of genistein on the UTP-activated $\mathrm{Cl}^{-}$secretion of the immortalized endometrial epithelial cells. (A) Representative $I_{\text {sc }}$ tracing in response to genistein (50 $\mu \mathrm{M}$, apical and basolateral) in the presence of UTP ( $5 \mu \mathrm{M}$, apical), and (B) Average changes in the $\mathrm{I}_{\mathrm{sc}}$ responding to genistein alone and in the presence of UTP, (C) Representative $I_{s c}$ tracing in response to UTP in the presence of genistein. (D) Average changes in the $\mathrm{I}_{\mathrm{sc}}$ responding to UTP alone and in the presence of genistein. Each value represents mean \pm SEM $(n=4-6)$. ${ }^{*} \mathrm{P}<0.01$ when compared to the control group with UTP alone by Student t-test.

$\mathrm{Cl}^{-}$channel blocker also reduced the genistein-stimulated $\mathrm{I}_{\text {sc }}$ by $65 \%$. In addition, blocking $\mathrm{Cl}^{-}$loading across the basolateral membrane with $200 \mu \mathrm{M}$ bumetanide, an inhibitor of $\mathrm{Na}^{+}-$ $\mathrm{K}^{+}-2 \mathrm{Cl}^{-}$cotransport, completely inhibited the increase in $\mathrm{I}_{\text {sc }}$ induced by genistein (Fig. 2).

To assess the involvement of genistein in the cAMP-activated $\mathrm{Cl}^{-}$secretion, we examined the effect of genistein in the presence of forskolin or IBMX, activators of CFTR via cAMP. As shown in Fig. 3, addition of $10 \mu \mathrm{M}$ forskolin or 100 $\mu \mathrm{M}$ IBMX to both the apical and basolateral solutions markedly increased the $\mathrm{I}_{\mathrm{sc}}$. The subsequent addition of $50 \mu \mathrm{M}$ genistein in the presence of forskolin or IBMX produced a slight further increase in the $\mathrm{I}_{\mathrm{sc}}$ as compared to the results of the addition of genistein alone (Fig. 3A-C). On the other hand, pretreatment with genistein also abolished the increased $\mathrm{I}_{\mathrm{sc}}$ induced by forskolin or IBMX (Fig. 3D-F).

$\mathrm{Cl}^{-}$secretion across the porcine endometrial epithelial cells has been stimulated by UTP via an increase in intracellular $\mathrm{Ca}^{2+}$ [33]. To further investigate the effect of genistein on the $\mathrm{Ca}^{2+}$-activated $\mathrm{Cl}^{-}$secretion, UTP was applied in the absence and in the presence of genistein. As shown in Fig. 4A, an apical addition of $5 \mu \mathrm{M}$ UTP caused a rapid increase in the $\mathrm{I}_{\mathrm{sc}}$ with a peak of $11.72 \pm 2.23 \mu \mathrm{A} / \mathrm{cm}^{2}$ followed by a sustained decrease in the $I_{\text {sc }}$ at $1.27 \pm 0.38 \mu \mathrm{A} /$ $\mathrm{cm}^{2}(\mathrm{n}=4)$ above the baseline level. A subsequent addition of genistein produced a further increase in the $\mathrm{I}_{\mathrm{sc}}$ which was not significantly different from the value observed when giving genistein alone (Fig. 4B-C). In contrast, the peak $\mathrm{I}_{\text {sc }}$ response induced by UTP was completely abolished after pretreatment with genistein (Fig. 4C-D).

Effects of genistein on membrane permeability

To assess the direct effects of genistein on apical and basolateral membrane permeability, we used amphotericin $\mathrm{B}(10 \mu \mathrm{M})$ to permeabilize one membrane of the cell 


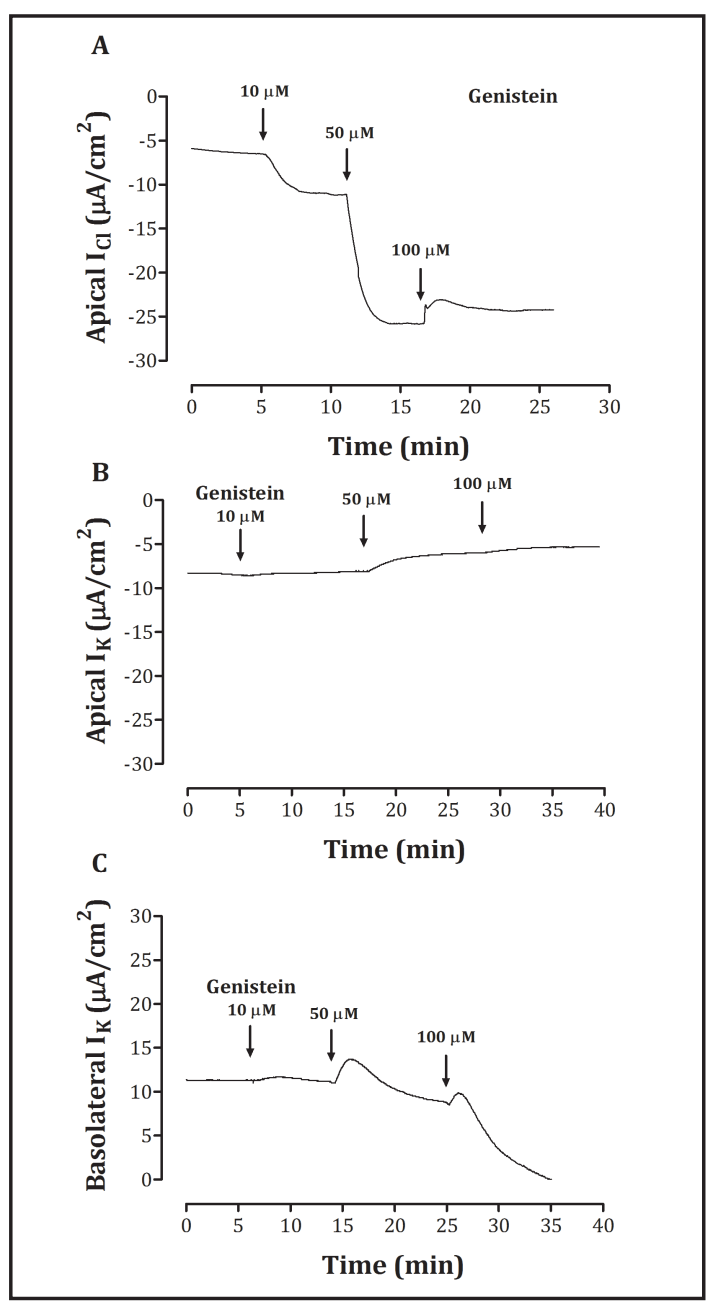

Fig. 5. Effect of genistein on membrane permeability of the immortalized endometrial epithelial cells. Representative tracings show the effects of genistein at concentrations of 10,50 and $100 \mu \mathrm{M}$ on (A) the apical membrane $\mathrm{Cl}^{-}$current $\left(\mathrm{I}_{\mathrm{Cl}}\right)$, (B) the apical membrane $\mathrm{K}^{+}$current $\left(\mathrm{I}_{\mathrm{Ka}}\right)$, and $(\mathrm{C})$ the basolateral membrane $\mathrm{K}^{+}$current $\left(\mathrm{I}_{\mathrm{Kb}}\right)$. Experiments were performed in an amphotericin B-permeabilized monolayer bathed in $\mathrm{Cl}^{-}$or $\mathrm{K}^{+}$gradient solutions (see methods).

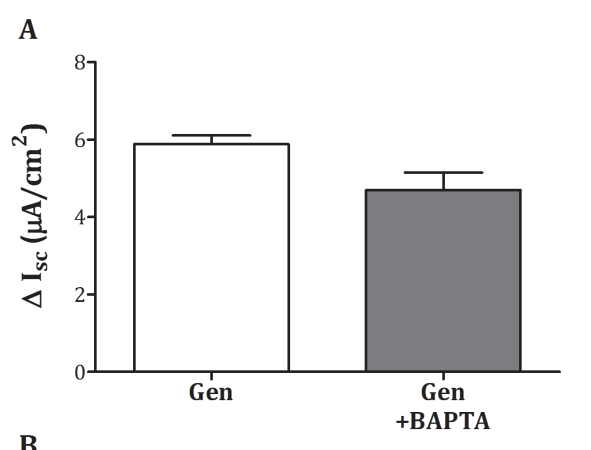

B

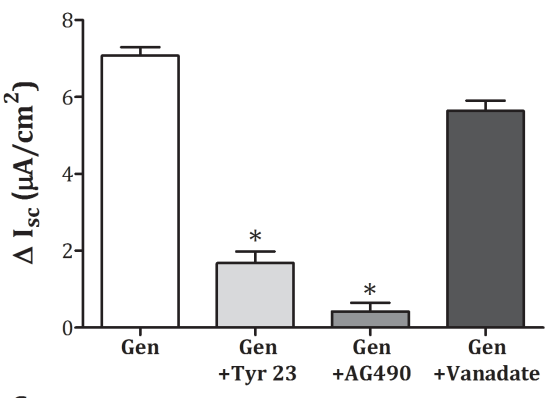

C

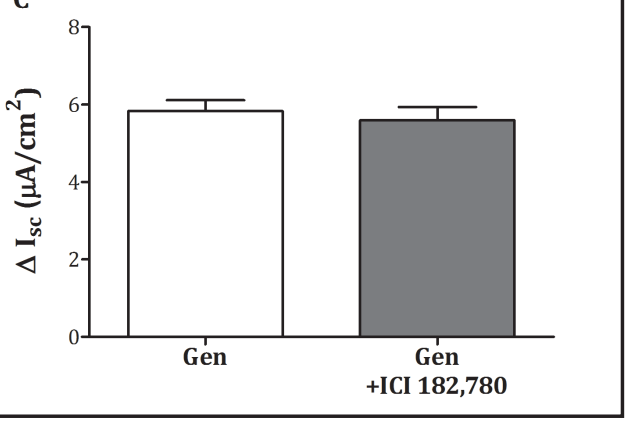

Fig. 6. Effect of $\mathrm{Ca}^{2+}$ chelating BAPTA-AM, tyrosine kinase inhibitors, tyrosine phosphatase inhibitor, and selective estrogen receptor inhibitor on the genistein-stimulated $\mathrm{I}_{\mathrm{sc}}$ of the immortalized endometrial epithelial cells. Bar graph shows the average changes in the $\mathrm{I}_{\mathrm{sc}}$ in response to genistein (Gen; $50 \mu \mathrm{M}$ ) alone and in the presence of (A) BAPTA-AM (50 $\mu \mathrm{M})$, (B) tyrphostin A23 (Tyr 23; $100 \mu \mathrm{M}), \operatorname{AG} 490(50 \mu \mathrm{M})$ or vanadate $(100 \mu \mathrm{M})$, and (C) ICI182,780 $(1 \mu \mathrm{M})$. All compounds were added to both, apical and basolateral solutions. Each value represents mean $\pm \operatorname{SEM}(n=3-6) .{ }^{*} \mathrm{P}<0.01$ when compared to the control group with genistein alone by Dunnett's test.

monolayers in order to exclusively study the permeability of the other membrane. As shown in Fig. 5A, when the basolateral membrane was permeabilized and bathed in a $\mathrm{Cl}^{-}$-gradient solution, genistein $(10$ and $50 \mu \mathrm{M})$ caused concentration-dependent increases in the apical $\mathrm{Cl}^{-}$current $\left(\mathrm{I}_{\mathrm{Cl}}\right)$ as represented by the negative deflection of the current. Genistein at 50 $\mu \mathrm{M}$ produced a maximum $\mathrm{I}_{\mathrm{Cl}}$ by $-8.69 \pm 1.39 \mu \mathrm{A} / \mathrm{cm}^{2}(\mathrm{n}=8)$ whereas high concentration of genistein $(100 \mu \mathrm{M})$ rapidly and slightly decreased the $\mathrm{I}_{\mathrm{Cl}}$. In a $\mathrm{K}^{+}$-gradient solution, genistein produced a concentration-dependent inhibition of the apical $\mathrm{K}^{+}$current $\left(\mathrm{I}_{\mathrm{Ka}}\right)$ as was shown by an increase in the current (Fig. $5 \mathrm{~B}$ ). Genistein at $50 \mu \mathrm{M}$ slightly inhibited $\mathrm{I}_{\mathrm{Ka}}$ by $2.18 \pm 0.61$ 
$\mu \mathrm{A} / \mathrm{cm}^{2}(\mathrm{n}=7)$. When the apical membrane was permeabilized with amphotericin $\mathrm{B}$, low concentrations of genistein $(10 \mu \mathrm{M})$ slightly increased the basolateral $\mathrm{K}^{+}$current $\left(\mathrm{I}_{\mathrm{Kb}}\right)$ while high concentrations $\left(50\right.$ and $100 \mu \mathrm{M}$ ) elicited an immediate increase in the $\mathrm{I}_{\mathrm{Kb}}$ followed by a gradual decrease in the $\mathrm{I}_{\mathrm{Kb}}$ which could not retain a steady state at a concentration of 100 $\mu \mathrm{M}$ (Fig. $5 \mathrm{C}$ ). Genistein at $50 \mu \mathrm{M}$ increased the $\mathrm{I}_{\mathrm{Kb}}$ by $2.90 \pm 0.49 \mu \mathrm{A} / \mathrm{cm}^{2}$ within $2-3 \mathrm{~min}$ and then gradually decreased to a sustained level below the baseline at $-17.06 \pm 4.12 \mu \mathrm{A} / \mathrm{cm}^{2}$ $(\mathrm{n}=6)$. Basolateral pretreatment with $5 \mathrm{mM} \mathrm{Ba}^{+}$, a non-specific $\mathrm{K}^{+}$channel blocker, abolished the increased $\mathrm{I}_{\mathrm{Kb}}$ and inhibited the sustained level response to genistein to -8.76 $\pm 2.69 \mu \mathrm{A}$ / $\mathrm{cm}^{2}(\mathrm{n}=3)$.

\section{Mechanism of genistein action on $\mathrm{Cl}$ secretion}

To assess whether genistein activated $\mathrm{Cl}^{-}$secretion was mediated by intracellular $\mathrm{Ca}^{2+}$, the genistein response was tested in the presence of BAPTA-AM, a cell permeable intracellular $\mathrm{Ca}^{2+}$ chelating agent. Pretreatment of the monolayer with $50 \mu \mathrm{M}$ BAPTA-AM in the apical and basolateral solutions for 30 min slightly decreased the baseline and did not affect the genistein-induced increase in the $\mathrm{I}_{\mathrm{sc}}$ (Fig. 6A). However, BAPTA-AM completely inhibited the increase in the $I_{s c}$ induced by UTP $\left(-0.25 \pm 0.05 \mu \mathrm{A} / \mathrm{cm}^{2}, \mathrm{n}=3\right)$. These results suggest that the genistein response does not involve $\mathrm{Ca}^{2+}$ mobilization.

Since $\mathrm{Cl}^{-}$secretion through CFTR has been shown to be regulated by phosphorylation and dephosphorylation of the nucleotide binding domain, we further examined the effect of tyrosine kinase inhibitors, tyrphostin A23 or AG490, or tyrosine phosphataseinhibitor, vanadate, on the genistein-stimulated $I_{s c}$ response. The experiment was performed by the pretreatmentofthemonolayerswithinhibitorsadded totheapicaland basolateralsolutionsfor $30 \mathrm{~min}$ prior to the genisteinapplication. Tyrphostin $\mathrm{A} 23(100 \mu \mathrm{M})$ decreased the baseline $\mathrm{I}_{\mathrm{sc}}$ by-0.76 \pm 0.19 $\mu \mathrm{A} / \mathrm{cm}^{2}(\mathrm{n}=4)$ and significantly reduced the genistein-induced increase in the $\mathrm{I}_{\mathrm{sc}}$ by $80 \%$ (Fig. 6B). Like tyrphostin A23, AG490 $(50 \mu \mathrm{M})$ had no effect on the basal $\mathrm{I}_{\mathrm{sc}}$ and markedly abolished the genistein-increased $\mathrm{I}_{\mathrm{sc}}$ by $93 \%(\mathrm{n}=4)$. Addition of vanadate $(100 \mu \mathrm{M})$ slightly increased the baseline $I_{s c}$ by $0.66 \pm 0.30 \mu \mathrm{A} / \mathrm{cm}^{2}(\mathrm{n}=4)$; however, it failed to inhibit the genistein-induced increase in the $\mathrm{I}_{\mathrm{sc}}$.

To further investigate whether genistein stimulated $\mathrm{Cl}^{-}$secretion via estrogen receptors, we compared the acute effects of genistein with that of $17 \beta$-estradiol and examined the effect of genistein in the presence of a selective estrogen receptor antagonist ICI182,780. Apical and basolateral additions of $17 \beta$-estradiol at concentration of 1,10 and $100 \mathrm{nM}$ had no effect on the $\mathrm{I}_{\mathrm{sc}^{\circ}}$. Moreover, pretreatment with ICI182, $780(1 \mu \mathrm{M})$ did not affect the basal $\mathrm{I}_{\mathrm{sc}}\left(0.07 \pm 0.14 \mu \mathrm{A} / \mathrm{cm}^{2}, \mathrm{n}=3\right)$ and failed to inhibit the increase in the $\mathrm{I}_{\mathrm{sc}}$ that was induced by genistein (Fig. 6C).

\section{Discussion}

Our study is the first evidence found that genistein stimulates $\mathrm{Cl}^{-}$secretion in endometrial epithelial cells. The genistein-activated $\mathrm{Cl}^{-}$secretion was supported by experiments in both intact and permeabilized monolayers. First, the genistein-induced increase in $\mathrm{I}_{\mathrm{sc}}$ was almost abolished by glibenclamide, NPPB and CFTRinh-172, and partly inhibited by DIDS. These are all well-known apical $\mathrm{Cl}^{-}$channel blockers. Second, the genistein response was blocked by bumetanide, a $\mathrm{Na}^{+}-\mathrm{K}^{+}-2 \mathrm{Cl}^{-}$cotransport blocker known to inhibit $\mathrm{Cl}^{-}$entry via the basolateral membrane. Third, the genistein response did not involve $\mathrm{Na}^{+}$absorption as it was insensitive to the $\mathrm{Na}^{+}$channel blocker amiloride. Finally, genistein increased both the apical $\mathrm{Cl}^{-}$current and basolateral $\mathrm{K}^{+}$current and it is general knowledge that an increased apical $\mathrm{Cl}^{-}$ permeability coupled with an increased basolateral $\mathrm{K}^{+}$permeability are required to sustain a driving force for $\mathrm{Cl}^{-}$secretion [32].

Genistein elicited concentration dependent changes in the $\mathrm{I}_{\text {sc }}$ and the apical $\mathrm{Cl}^{-}$current. Genistein, at concentrations $\leq 50 \mu \mathrm{M}$, both the $\mathrm{I}_{\mathrm{sc}}$ and the apical Cl- current were stimulated in a concentration dependent manner although both were inhibited at a high concentration 
$(100 \mu \mathrm{M})$. The inhibitory effects of genistein ( $>50 \mu \mathrm{M})$ are also observed in rat distal colons and nasal epithelial tissues $[11,13]$. This is possibly due to the inhibition of $\mathrm{K}^{+}$channels. Genistein also inhibits basolateral $\mathrm{Ca}^{2+}$-activated $\mathrm{K}^{+}$channels in the colon [11]. In CFTR overexpressing cells, genistein produces a biphasic action on CFTR activity, i.e., stimulatory effect at low concentrations and inhibitory effect at high concentrations [22]. This study suggests that at least two binding sites are required for a direct binding of genistein to the CFTR. One at high affinity reduces the closing of the channel whereas a low affinity reduces the channel's opening [22]. In the present study, genistein, when applied at high concentration $(100 \mu \mathrm{M})$, reduced both the apical $\mathrm{K}^{+}$current and the apical $\mathrm{Cl}^{-}$current (Fig. 5). This suggests that the inhibitory effect of genistein on the $\mathrm{I}_{\mathrm{sc}}$ is likely a result of the inhibitions of both the apical $\mathrm{Cl}^{-}$and $\mathrm{K}^{+}$channels.

Genistein has been reported to activate CFTR in the CFTR overexpression system, cultured cell lines and native epithelial tissues [11, 14, 17, 20, 22, 23, 36]. Some studies have shown that genistein alone activates CFTR $[14,23]$ whereas other studies have shown that a cAMP dependent phosphorylation of CFTR through forskolin is required for the stimulatory effect of genistein $[11,23,36]$. However, the pre-activation with cAMP was not required in the present study since genistein directly stimulated the $\mathrm{I}_{\mathrm{sc}}$. This increased $\mathrm{I}_{\mathrm{sc}}$ by genistein was significantly reduced in the presence of forskolin, an activator of adenylate cyclase or IBMX, a phosphodiesterase inhibitor. The forskolin/IBMX-stimulated $\mathrm{I}_{\mathrm{sc}}$ was also abolished in the presence of genistein. These findings are consistent with previous studies which have indicated that genistein shares a common $\mathrm{Cl}^{-}$secretory pathway which is activated via cAMPdependent agonists [14, 36], and that the genistein response is at least involved in cAMPactivated $\mathrm{Cl}^{-}$secretion through CFTR. The participation of CFTR in the genistein response is confirmed by the observations that both, well-known and specific CFTR blockers, reduces the genistein-activated $\mathrm{I}_{\mathrm{sc}}$. Although not investigated in our study, an increase in intracellular cAMP is not required for the genistein-stimulated $\mathrm{Cl}^{-}$secretion $[19,23]$. Therefore, in the endometrial epithelial cells, genistein appears to stimulate $\mathrm{Cl}^{-}$secretion via the direct activation of CFTR. Patch-clamp studies of heterologously expressed CFTR have reported that genistein increases the activity of CFTR by a direct interaction with NBD2 of the CFTR $[17,20]$.

Genistein has been reported to modulate $\mathrm{K}^{+}$transport in native tissues and cultured epithelial and nonepithelial cells. It inhibits basolateral $\mathrm{Ca}^{2+}$-activated $\mathrm{K}^{+}$channels in the human rectum, the rat colon and the CFTR-expressing colonic cell line [11, 12, 14, 19]. However, it stimulates small conductance $\mathrm{Ca}^{2+}$-activated $\mathrm{K}^{+}$channels in the collecting ducts [37]. The small conductance $\mathrm{Ca}^{2+}$-activated $\mathrm{K}^{+}$channel mRNA is also expressed in PEG cells and is regulated by $17 \beta$-estradiol [35]. Our results demonstrated that genistein the maximum concentration produced a biphasic response in the basolateral $\mathrm{K}^{+}$current. This was an initial increase in the $\mathrm{K}^{+}$current followed by a long-lasting decrease in the $\mathrm{K}^{+}$current to a persistent level below the baseline (Fig. 5C). The increased basolateral $\mathrm{K}^{+}$current in response to genistein was completely abolished in the presence of the non-selective $\mathrm{K}^{+}$ channel blocker $\mathrm{BaCl}_{2}$. However, the specific types of the $\mathrm{K}^{+}$channel in response to genistein have yet to be clarified. It is general knowledge that the activation of the basolateral $\mathrm{K}^{+}$ channel is required to hyperpolarize the membrane producing the driving force for $\mathrm{Cl}^{-}$ secretion. Therefore, in our present study, genistein increases the $\mathrm{I}_{\mathrm{sc}}$ and thus increases the $\mathrm{Cl}^{-}$secretion by activating both the basolateral $\mathrm{K}^{+}$current and the apical $\mathrm{Cl}^{-}$current. The subsequently decreased $\mathrm{I}_{\mathrm{sc}}$ is likely secondary to a sustained decrease in the basolateral $\mathrm{K}^{+}$ current. Although genistein inhibited the apical $\mathrm{K}^{+}$current in the current study, it seems to have less effect on the $\mathrm{I}_{\mathrm{sc}}$ response when induced by genistein. Thus, the basolateral $\mathrm{K}^{+}$ permeability appears to be the rate limiting step in respect to $\mathrm{Cl}^{-}$secretion as has been reported previously [32].

Previous studies done on porcine endometrial epithelial cells have reported that UTP activates $\mathrm{Cl}^{-}$secretion via an increase in the intracellular $\mathrm{Ca}^{2+}$ and in PKC stimulation $[33,34]$. We further examined the effects of genistein in the presence of UTP. UTP rapidly increased the $\mathrm{I}_{\mathrm{sc}}$ which was completely abolished in the presence of the intracellular $\mathrm{Ca}^{2+}$ 
chelating BAPTA-AM. This confirms a dependence on intracellular $\mathrm{Ca}^{2+}$ mobilization and an activation of $\mathrm{Ca}^{2+}$-activated $\mathrm{Cl}^{-}$secretion by UTP. However, the increase in the $\mathrm{I}_{\mathrm{sc}}$ induced by genistein was not affected by the presence of UTP. This finding suggests the possibility that genistein may stimulate $\mathrm{Cl}^{-}$secretion directly via CFTR as has been reported by others $[17$, 20]. Although UTP has been shown to activate CFTR [34, 38], it is likely that the UTP-induced transient increase in $\mathrm{I}_{\mathrm{sc}}$ could be a result of the stimulation of $\mathrm{Cl}^{-}$secretion, primarily through $\mathrm{Ca}^{2+}$-activated $\mathrm{Cl}^{-}$channels. Apart from a direct interaction with CFTR, genistein may increase CFTR localization in the plasma membrane $[25,26]$.

In this present study, the UTP response was completely abolished in the presence of genistein. This observation indicates that genistein possibly modulates the, as yet, unknown signaling mechanisms responsible for UTP-stimulated $\mathrm{Cl}^{-}$secretion. Some possibilities explaining the lack of UTP response in the presence of genistein are; First, genistein, a specific tyrosine kinase inhibitor, has been shown to inhibit enzymes involved in the turnover of phosphoinositol (phosphatidylinositol-4-phosphate and phosphatidylinositol4,5-biphosphate (PIP2) kinases), and hence reduces PIP2 which is the substrate for phospholipase $C$ to produce inositol-1,4,5-triphosphate (IP3) and diacylglycerol [39]. These signaling molecules are involved in the UTP-activated $\mathrm{Cl}^{-}$secretion in the PEG cells $[33,34]$. Second, it could be explained by an inhibitory effect of genistein on the apical and basolateral $\mathrm{K}^{+}$currents $\left(\mathrm{I}_{\mathrm{kb}}\right)$ (Fig. 5). A sustained and marked decrease following an immediate increase in the $\mathrm{I}_{\mathrm{kb}}$ may prevent the stimulatory effects of UTP on the $\mathrm{I}_{\mathrm{sc}}$. The apical small-conductance $\mathrm{Ca}^{2+}$-activated $\mathrm{K}^{+}$channels in the PEG cells are activated by UTP [35]. A reduction in $\mathrm{K}^{+}$ secretion through $\mathrm{K}^{+}$channels by genistein would depolarize the membranes, thus reducing the driving force for the UTP-stimulated $\mathrm{Cl}^{-}$secretion. Third, genistein appears to partially activate the $\mathrm{Ca}^{2+}$-activated $\mathrm{Cl}^{-}$channels since approximately $65 \%$ of the genistein response was also inhibited in the presence of DIDS (Fig. 2). Although, genistein action is independent of intracellular $\mathrm{Ca}^{2+}$, the participation of the $\mathrm{Ca}^{2+}$-activated $\mathrm{Cl}^{-}$channels in the genistein response may thereby reduce a further increase in the $\mathrm{I}_{\mathrm{sc}}$ upon the application of UTP. However, the exact mechanism could be the subject of further studies.

Genistein has been reported to regulate $\mathrm{Cl}^{-}$secretion through the modulation of the phosphorylated state of CFTR by protein kinases and protein phosphatases [18, 19, 23]. Indeed, genistein has been shown to inhibit tyrosine kinase [40] and regulation of tyrosine phosphorylation has been proposed in modulating the CFTR and thus $\mathrm{Cl}^{-}$secretion in both native tissues and cultured cells $[14,23]$. In the present study, tyrphostin A23, a tyrosine kinase inhibitor that is structurally and mechanistically different from genistein reduced the basal $\mathrm{I}_{\mathrm{sc}}$ and limited the genistein-increased $\mathrm{I}_{\mathrm{sc}^{\circ}}$. These findings resemble those observed in the previous studies with renal epithelial A6 cells, human colonic T84 cells and mouse jejunum $[14,15,23]$. However, the inhibitory effect of tyrphostin A23 on the basal $I_{s c}$ is unknown and is suggested that it involves the direct blockade of the CFTR or inhibition of the protein kinase $\mathrm{A}$ as has been observed at high concentrations of the erbstatin compound [23]. The genistein response was also abolished in the presence of AG490, a tyrphostin that specifically inhibits tyrosine-specific protein kinase [41]. The different effects of tyrosine kinase inhibitors on transport function is also dependent on the structural nature of the inhibitor as has been proposed by Niisato et al. [15]. Genistein, a soy isoflavone, has a structure which is mechanistically different from erbstatin-derived tyrphostins. However, in the present study, daidzein, an isoflavone that is a structural analog of genistein, had less of a stimulatory effect on the basal $I_{s c}$ when compared to that of genistein. This is also suggestive of the complex role of isoflavones on ion transport functions. Daidzein has been reported to have no activity or less specificity than genistein for the inhibition of protein tyrosine kinase [39]. The lack of a daidzein effect on cAMP-stimulated $\mathrm{Cl}^{-}$secretion has been evidenced in T84 cells [23]. The reduced genistein response in the presence of tyrphostin A23 or AG490 suggests that genistein acts in the stimulation of $\mathrm{Cl}^{-}$secretion via the inhibition of a tyrosine kinase. Additionally, pretreatment with vanadate, a tyrosine phosphatase inhibitor, failed to inhibit the stimulatory effects of genistein on the $I_{s c}$ suggesting that the inhibition of protein tyrosine phosphatase does not involve a genistein response in the PEG cells. Similar 
findings are also observed in Hi-5 insect cells and CFTR expressing NIH3T3 fibroblast cells in demonstrating the lack of a genistein effect in the presence of vanadate [22]. All of the present findings indicate that the effects of genistein on CFTR and thus, $\mathrm{Cl}^{-}$secretion appear to be modulated by a tyrosine kinase-dependent phosphorylation pathway.

Since genistein is structurally related to estradiol, its effect is suggested to be mediated through estrogen receptors (ER) with expression on the target organs. Genistein binds to both ER- $\alpha$ and ER- $\beta$ subtypes, with a higher affinity to ER- $\beta$ when compared to endogenous estrogen [2]. Estrogen and genistein have been reported to act via the ER-mediated pathway in the regulation of protein expressions which include protein transporters and receptors. In particular, treatments of kidney BHK cells with genistein $(30 \mu \mathrm{M})$ for a period of 24 hours has been shown to up-regulate CFTR expression [42]. The effect of genistein on protein expression appears to be modified by ligand dose, ER subtypes and gender. Al-Nakkash [43] had shown evidence on the stimulatory effects of genistein on jejunal chloride secretion in male mice via an ER-dependent mechanism and in female mice via an ER-independent mechanism. In addition, the expressions of ER $\alpha$ and ER $\beta$ in the endometrial cells varied dependent upon the concentration of genistein [44]. On the other hand, estrogen and genistein has been shown to regulate protein functions independent of protein expression. Studies in the colonic epithelium have demonstrated that $17 \beta$-estradiol acutely modulates the $\mathrm{Cl}^{-}$secretory process via a membrane ER [45]. Genistein has also been reported to acutely stimulate $\mathrm{HCO}_{3}^{-}$ secretion in mouse duodenum, primarily through an ER-dependent pathway [46]. Contrastingly, in our study, the acute effect of genistein on $\mathrm{Cl}^{-}$secretion is not mediated through ER as the selective estrogen receptor antagonist, ICI182,780, failed to inhibit the genistein-stimulated $\mathrm{I}_{\mathrm{sc}}$. Moreover, $17 \beta$-estradiol did not affect the basal $\mathrm{I}_{\mathrm{sc}}$. The ER-independent acute response of genistein on chloride secretion may be of benefit to all tissues and either gender; even though the specific subtypes of estrogen receptors do not express themselves.

Any alterations in uterine volume and electrolyte composition, away from the norm, may cause an unfavorable uterine environment for many reproductive processes and may lead to infertility. In cystic fibrosis, reduced fertility is the result of a loss of CFTR-mediated anion secretions and thus, a reduction of fluid secretion from the glands into the uterine lumen. In this case, genistein may be used as pharmacological intervention for infertility that is associated with cystic fibrosis. Conversely, daily consumption of food or plants high in genistein or isoflavones has shown incidences of infertility in sheep and cheetahs $[47,48]$, but little information is known about its effects in humans. The cause of infertility may be the result of the accumulation of excessive fluid in the uterine lumen as has been supported by a recent study in rat uterus that has reported excessive fluid secretion and high luminal fluid volume with high genistein treatments [7]. In this study, subcutaneous injections with high dose genistein (100 mg/kg/day) for 3 days resulted in plasma levels of $15 \mu \mathrm{M}$ which is comparable to the results of $\mathrm{EC}_{50}$ in the genistein response in our present study. By comparison, rats consuming a diet containing $750 \mu \mathrm{g} / \mathrm{g} /$ day of genistein have been shown to generate serum genistein concentrations of $1 \mu \mathrm{M}$ [49]. The excessive fluid accumulation in the uterine lumen may cause adverse effects on many reproductive processes including; sperm capacitation, fertilization and embryo implantation. While the observed adverse effects of genistein on the uterine fluid secretions are related to high daily or long term consumptions of genistein, our present study provides evidence on the direct action of genistein-induced fluid secretions and has demonstrated that the major component of the fluid secreted is likely $\mathrm{Cl}^{-}$. From this information, given the acute and transient effects of genistein on $\mathrm{Cl}^{-}$ secretion, it is implied that short term or intermittent consumption of genistein or isoflavone containing diet is unlikely to interfere with the normal uterine volume and composition as well as one cause of infertility. Nevertheless, high intake or long term consumption of these isoflavones should be taken into consideration as to the adverse effects that have been found in humans and in animals.

In conclusion, the present study has demonstrated that the isoflavone genistein acutely stimulates $\mathrm{Cl}^{-}$secretion in porcine endometrial epithelial cells by activation of apical $\mathrm{Cl}^{-}$and basolateral $\mathrm{K}^{+}$conductance. The genistein-activated $\mathrm{Cl}^{-}$secretion may involve the direct 
activation of CFTR which appears to be mediated by the tyrosine-dependent phosphorylation pathway. Our study provides functional information of the action of genistein on the modulation of $\mathrm{Cl}^{-}$secretion in the endometrial epithelium. The use of soy-derived isoflavone genistein may be of benefit as a pharmacotherapeutic agent for the treatment of electrolyte transport disorders in epithelial tissues.

\section{Acknowledgments}

This work was fully supported by research grants from Srinakharinwirot University (374/2552) and is supported, in part, by The Thailand Research Fund (RMU4980026) awarded to Chatsri Deachapunya. We wish to thank Miss Norathee Buathong for her help with cell culturing and the experiment's setup.

\section{References}

1 Cederroth CR, Nef S: Soy, phytoestrogens and metabolism: A review. Mol Cell Endocrinol 2009;304:30-42.

-2 Kuiper GG, Lemmen JG, Carlsson B, Corton JC, Safe SH, van der Saag PT, van der Burg B, Gustafsson JA: Interaction of estrogenic chemicals and phytoestrogens with estrogen receptor beta. Endocrinology 1998;139:4252-4263.

3 Schmidt S, Degen GH, Seibel J, Hertrampf T, Vollmer G, Diel P: Hormonal activity of combinations of genistein, bisphenol A and 17beta-estradiol in the female Wistar rat. Arch Toxicol 2006;80:839-845.

-4 Anderson JJ, Anthony MS, Cline JM, Washburn SA, Garner SC: Health potential of soy isoflavones for menopausal women. Public Health Nutr 1999;2:489-504.

-5 Goldwyn S, Lazinsky A, Wei H: Promotion of health by soy isoflavones: efficacy, benefit and safety concerns. Drugs Metabol Drug Interact 2000;17:261-289.

-6 Jefferson W. Williams CJ: Circulating levels of genistein in the neonate, apart from dose and route, predict future adverse female reproductive outcomes. Reprod Toxicol 2011;31:272-279.

7 Salleh N, Helmy MM, Fadila KN, Yeong SO: Isoflavone genistein induces fluid secretion and morphological changes in the uteri of post-pubertal rats. Int J Med Sci 2013;10:665-675.

8 Moghissi KS: Vaginal fluid constituents. In The Biology of the Fluids of the Female Genital Tract. New York Elsevier, North-Holland Press 1979, pp 13-23.

9 Duncan SLB, Levin RJ: Transuterine, transendocervical and transvaginal potential differences in conscious woman measured in situ. J Physiol 1976;259:27-28.

10 Chan HC, Qiong HE, Ajonuma LC, Wang XF: Epithelial channels in the regulation of female reproductive tract fluid microenvironment: implications in fertility and infertility. Acta Physiologica Sinica 2007;59:495504.

11 Diener M, Hug F: Modulation of Cl- secretion in rat distal colon by genistein, a protein tyrosine kinase inhibitor. Eur J Pharmacol 1996;299:161-170.

-12 Illek B, Fischer H, Machen TE: Alternate stimulation of apical CFTR by genistein in epithelia. Am J Physiol Cell Physiol 1996;270:C265-C275.

13 Mall M, Wissner A, Seydewitz HH, Hübner M, Kuehr J, Brandis M, Greger R, Kunzelmann K: Effect of genistein on native epithelial tissue from normal individuals and CF patients and on ion channels expressed in Xenopus oocytes. Br J Pharmacol 2000;130:1884-1892.

14 Baker MJ, Hamilton KL: Genistein stimulates electrogenic $\mathrm{Cl}^{+}$secretion in mouse jejunum. Am J Physiol Cell Physiol 2004;287:C1636-C1645.

-15 Niisato N, Ito Y, Marunaka Y: Activation of Cl- channel and $\mathrm{Na}^{+} / \mathrm{K}^{+} / 2 \mathrm{Cl}^{-}$cotransporter in renal epithelial A6 cells by flavonoids: genistein, daidzein, and apigenin. Biochem Biophys Res Commun 1999;254:368-371.

16 Andersson C, Servetnyk Z, Roomans GM: Activation of CFTR by genistein in human airway epithelial cell lines. Biochem Biophys Res Commun 2003;308:518-522. 
Deachapunya/Poonyachoti: Genistein Activates Chloride Secretion

17 French PJ, Bijman J, Bot AG, Boomaars WE, Scholte BJ, de Jonge HR: Genistein activates CFTR Clchannels via a tyrosine kinase- and protein phosphatase-independent mechanism. Am J Physiol 1997;273:C747-C753.

18 Illek B, Fischer H: Flavonoids stimulate Cl- conductance of human airway epithelium in vitro and in vivo. Am J Physiol 1998;275:L902-L910.

-19 Sears CL, Firoozmand F, Mellander A, Chambers FG, Eromar IG, Bot AG, Scholte B, De Jonge HR, Donowitz M: Genistein and tyrphostin 47 stimulate CFTR-mediated Cl- secretion in T84 cell monolayers. Am J Physiol 1995;269:G874-G882.

20 Weinreich F, Wood PG, Riordan JR, Nagel G: Direct action of genistein on CFTR. Pflugers Arch 1997;434:484-491.

21 Illek B, Fischer H, Santos GF, Widdicombe JH, Machen TE, Reenstra WW: cAMP-independent activation of CFTR Cl channels by the tyrosine kinase inhibitor genistein. Am J Physiol 1995;268:C886-C893.

22 Wang F, Zeltwanger S, Yang IC, Nairn AC, Hwang TC: Actions of genistein on cystic fibrosis transmembrane conductance regulator channel gating. Evidence for two binding sites with opposite effects. J Gen Physiol 1998;111:477-490.

23 Illek B, Fischer H, Machen TE: Alternate stimulation of apical CFTR by genistein in epithelia. Am J Physiol 1996;270:C265-C275.

24 Chao PC, Hamilton KL: Genistein stimulates electrogenic Cl- secretion via phosphodiesterase modulation in the mouse jejunum. Am J Physiol Cell Physiol 2009;297:C688-C698.

25 Lehrich RW, Aller SG, Webster P, Marino CR, Forrest JN Jr: Vasoactive intestinal peptide, forskolin, and genistein increase apical CFTR trafficking in the rectal gland of the spiny dogfish, Squalus acanthias. Acute regulation of CFTR trafficking in an intact epithelium. J Clin Invest 1998;101:737-745.

26 Al-Nakkash L, Batia L, Bhakta M, Peterson A, Hale N, Skinner R, Sears S, Jensen J: Stimulation of murine intestinal secretion by daily genistein injections: gender-dependent differences. Cell Physiol Biochem 2011;28:239-250.

27 Matthews CJ, Thomas EJ, Redfern CPF, Hirst BH: Ion transport by human endometrium in vitro. Human Reprod 1993;8:1510-1515.

28 Vetter AE, O'Grady SM: Mechanisms of electrolyte transport across the endometrium I. Regulation by PGF2 $\alpha$ and cAMP. Am J Physiol 1996;270:663-672.

29 Deachapunya C, Palmer-Densmore M, O'Grady SM: Insulin stimulates transepithelial sodium transport by activation of a protein phosphatase that increases $\mathrm{Na}^{+}-\mathrm{K}^{+}$ATPase activity in endometrial epithelial cells. J Gen Physiol 1999;114:561-574.

-30 Deachapunya C, O'Grady SM: EGF regulates the transition from basal sodium absorption to anion secretion in cultured endometrial epithelial cells. J Cell Physiol 2001;186:243-250.

31 Chan HC, Fong SK, Chung YM, Wong PYD: Stimulation of anion secretion by $\beta$-adrenoreceptors in the mouse endometrial epithelium. J Physiol 1997;501:517-525.

-32 Deachapunya C, O'Grady SM: Regulation of chloride secretion across porcine endometrial epithelial cells by prostaglandin E2. J Physiol 1998;508:31-47.

-33 Palmer-Densmore M, Deachapunya C, O'Grady SM: UTP-dependent inhibition of $\mathrm{Na}^{+}$absorption requires activation of PKC in endometrial epithelial cells. J Gen Physiol 2002;120:897-906.

- 34 Palmer ML, Lee SY, Carlson D, Fahrenkrug S, O'Grady SM: Stable knockdown of CFTR establishes a role for the channel in P2Y receptor-stimulated anion secretion. J Cell Physiol 2006;206:759-70.

- 35 Palmer M, Schiller KR, O'Grady SM: Apical SK potassium channels and $\mathrm{Ca}^{2+}$-dependent anion secretion in endometrial epithelial cells. J Physiol 2008;586:717-726.

36 Hwang TC, Wang F, Yang IC, Reenstra WW: Genistein potentiates wild-type and delta F508-CFTR channel activity. Am J Physiol 1997;273:C988-C998.

37 Wang W, Lerea KM, Chan M, Giebisch G: Protein tyrosine kinase regulates the number of renal secretory K channels. Am J Physiol Renal Physiol 2000;278:F165-F171.

-38 Namkung W, Finkbeiner WE, Verkman AS: CFTR-adenylyl cyclase I association responsible for UTP activation of CFTR in well-differentiated primary human bronchial cell cultures. Mol Biol Cell 2010;21:2639-2648.

-39 Polkowski K, Mazurek AP: Biological properties of genistein. A review of in vitro and in vivo data. Acta Pol Pharm 2000;57:135-155. 
-40 Akiyama T, Ishida J, Nakagawa S, Ogawara H, Watanabe SI, Itoh N, Shibuya M, Fukami Y: Genistein, a specific inhibitor of tyrosine-specific protein kinases. J Biol Chem 1987;262:5592-5595.

- 41 Constantin G, Brocke S, Izikson A, Laudanna C, Butcher EC: Tyrphostin AG490, a tyrosine kinase inhibitor, blocks actively induced experimental autoimmune encephalomyelitis. Eur J Immunol 1998;28:3523-3529.

42 Schmidt A, Hughes LK, Cai Z, Mendes F, Li H, Sheppard DN, Amaral MD: Prolonged treatment of cells with genistein modulates the expression and function of the cystic fibrosis transmembrane conductance regulator. Br J Pharmacol 2008;153:1311-1323.

-43 Al-Nakkash L: Genistein stimulates jejunal chloride secretion via sex-dependent, estrogen receptor or adenylate cyclase mechanisms. Cell Physiol Biochem 2012;30:137-150.

-44 Staar S, Richter DU, Makovitzky J, Briese V, Bergemann C: Stimulation of endometrial glandular cells with genistein and daidzein and their effects on ERalpha- and ERbeta-mRNA and protein expresion. Anticancer Res 2005;25:1713-1718.

45 Chondliffe SB, Doolan CM, Harvey BJ: 17beta-oestradiol acutely regulates $\mathrm{Cl}^{-}$secretion in rat distal colonic epithelium. J Physiol 2001;530:47-54.

46 Tuo B, Wen G, Song P, Xu J, Liu X, Seidler U, Dong H: Genistein stimulates duodenal $\mathrm{HCO}_{3}$ - secretion through PI3K pathway in mice. Eur J Pharmacol 2011;651:159-167.

-47 Bennetts HW, Underwood E: The oestrogenic effects of subterranean clover (trifolium subterraneum); uterine maintenance in the ovariectomised ewe on clover grazing. Aust J Exp Biol Med Sci 1951;2924929253.

-48 Setchell KD, Gosselin SJ, Welsh MB, Johnston JO, Balistreri WF, Kramer LW, Dresser BL, Tarr MJ: Dietary estrogens--a probable cause of infertility and liver disease in captive cheetahs. J Gastroenterology 1987;93:225-233.

49 Santell RC, Chang YC, Nair MG, Helferich WG: Dietary genistein exerts estrogenic effects upon the uterus, mammary gland and the hypothalamic/pituitary axis in rats. J Nutr 1997;127:263-269. 